\title{
A NEW SEXUALLY DIMORPHIC SPECIES OF THE GENUS ORIBATELLA (ACARI, ORIBATIDA, ORIBATELLIDAE) FROM RUSSIA
}

\author{
Sergey G. Ermilov ${ }^{1}$, Alexander A. Khaustov ${ }^{1}$, Omid Joharchi ${ }^{1}$ \\ Ismail DöKeR ${ }^{1,2}$ and Vladimir A. Khaustov ${ }^{1}$ \\ ${ }^{1}$ Tyumen State University, Institute of Environmental and Agricultural Biology (X-BIO) \\ Lenina str. 25, 625000 Tyumen, Russia \\ E-mail:ermilovacari@yandex.ru; https://orcid.org/0000-0002-0913-131X \\ E-mail: alkhaustov@mail.ru; https://orcid.org/0000-0002-0306-112X \\ E-mail: o.dzhokharchi@utmn.ru; https://orcid.org/0000-0002-2741-4946 \\ E-mail:i.doker@utmn.ru; https://orcid.org/0000-0002-1412-1554 \\ E-mail: khaustov93@mail.ua; https://orcid.org/0000-0003-2831-7213 \\ ${ }^{2}$ Cukurova University, Agricultural Faculty, Department of Plant Protection, Acarology Lab \\ 01330 Adana, Turkey
}

A new oribatid mite species of the genus Oribatella (Oribatida, Oribatellidae) - Oribatella altaica Ermilov sp. n. - is described from soil-litter in Altai mountains, Russia; it is showing an interesting sexual dimorphism in the structure of the posterior part of notogaster (large unpaired concavity bearing a pair of porose areas $A 3$ present in males versus concavity absent, $A 3$ located openly on notogastral surface in females). In addition, data on the known sexually dimorphic Oribatella species are presented.

Key words: oribatellid mites, taxonomy, morphology, sexual dimorphism, Altai.

\section{INTRODUCTION}

The genus Oribatella (Acari, Oribatida, Oribatellidae) was proposed by BANKs (1895) with Oribatella quadridentata Banks, 1895 as type species. At present, it comprises about 130 species, which have a cosmopolitan distribution collectively (Subías 2004, online version 2021). The generic characters were summarized by Behan-Pelletier and Eamer (2010) and Behan-Pelletier (2011). The identification keys to particular species of Oribatella have been presented by several authors (e.g. J. Balogh \& P. Balogh 2002, Weigmann 2006, Shtanchaeva \& Subías 2009, Behan-Pelletier 2011, Behan-Pelletier \& Walter 2012).

A new sexually dimorphic species of Oribatella found in the Altai Mts, SW Siberia of Russia. Cases of strong sexual dimorphism are relatively rare in Oribatida. According to Behan-Pelletier and Eamer (2010) and Behan-Pelletier (2015), only 77 species of more than 8000 known species of brachypyline oribatid mites show sexual dimorphism. Therefore, each new case is important in understanding this aspect among different groups of oribatid mites. The main goal of the current study is to describe and illustrate the new species. Moreover, we also summarize data on sexually dimorphic Oribatella species. 


\section{MATERIAL AND METHODS}

Specimens - Substrate samples (soil-litter) containing oribatid mites (including specimens of a new species) were collected by hand method from the Altai mountains, Russia, during our summer expedition in 2021. Mites were extracted using Berlese's funnels without electric lamps in laboratory conditions for five days and preserved in $70 \%$ of ethanol.

Specimens are deposited in two institutions: the Senckenberg Museum of Natural History, Görlitz, Germany (SMNH); and the Tyumen State University Museum of Zoology, Tyumen, Russia (TSUMZ).

Observation and documentation - Specimens were mounted in lactic acid on temporary cavity slides for measurements and illustrations. Body length was measured in lateral view, from tip of the rostrum to the posterior edge of the gastronotum. Notogastral width refers to maximum width of the notogaster in dorsal view. Lengths of body setae were measured in lateral aspect. All body measurements are presented in micrometers. Formulas for leg setation are given in parentheses according to the sequence trochanterfemur-genu-tibia-tarsus (famulus included). Formulas for leg solenidia are given in square brackets according to the sequence genu-tibia-tarsus. Drawings were made with a camera lucida using a Leica transmission light microscope "Leica DM 2500". Scanning electron microscope micrographs were made with the aid of a JEOL-JSM-6510LV SEM microscope.

Terminology - General morphological terminology used in this paper mostly follows that of F. Grandjean: see Travé and Vachon (1975) for references, Norton (1977) for leg setal nomenclature, and Norton and Behan-Pelletier (2009) for overview.

Abbreviations - Prodorsum: lam = lamella; $t u=$ tutorium; $g t=$ genal tooth; $r o, l e$, in, $b s, e x=$ rostral, lamellar, interlamellar, bothridial, and exobothridial seta, respectively; $D=$ dorsophragma; $P=$ pleurophragma. Notogaster: $l e n=$ lenticulus; $c o n=$ concavity; $c, l a, l m$, $l p, h, p=$ notogastral setae; $A a, A 1, A 2, A 3=$ notogastral porose areas; $i a, i m, i p$, ih, ips = lyrifissures; gla = opisthonotal gland opening. Gnathosoma: $a, m, h=$ subcapitular setae; or = adoral seta; $a s=$ axillary saccule; $d, l, c m, a c m, u l, s u, l t, v t$, sup, inf = palp setae; $\omega=$ palp solenidion; $c h a, c h b=$ cheliceral setae; $T g=$ Trägårdh's organ. Epimeral and lateral podosomal regions: $1 a, 1 b, 1 c, 2 a, 3 a, 3 b, 4 a, 4 b, 4 c=$ epimeral setae; $A h=$ humeral porose area; $P d I, P d I I=$ pedotectum I, II, respectively; $c$ US = custodium; dis = discidium; $c p c=$ circumpedal carina. Anogenital region: $g, a g$, an, ad = genital, aggenital, anal, and adanal seta, respectively; iad = adanal lyrifissure; $p o=$ preanal organ. Legs: $\mathrm{Tr}, \mathrm{Fe}, \mathrm{Ge}, \mathrm{Ti}, \mathrm{Ta}=$ trochanter, femur, genu, tibia, and tarsus, respectively; $p a=$ porose area; $\omega, \sigma, \varphi=$ solenidia; $\varepsilon=$ famulus; $d, l, v, e v, b v, f t$, tc, it, $p, u, a, s, p v, p l=$ setae.

\section{TAXONOMY}

Family Oribatellidae

Genus Oribatella Banks, 1895

Type species: Oribatella quadridentata Banks, 1895

\section{Oribatella altaica Ermilov sp. $\mathrm{n}$.}

(Figs 1-6)

Diagnosis - Body size: 348-398 × 207-240. Body surface microgranulate. Rostrum with small median concave. Inner margins of lamellae separated 
by elongate oval gap and fused basally by short translamella; outer and inner teeth of lamella similar in length. Rostral seta setiform, heavily ciliated unilaterally; lamellar seta bacilliform, barbed; interlamellar seta longest on

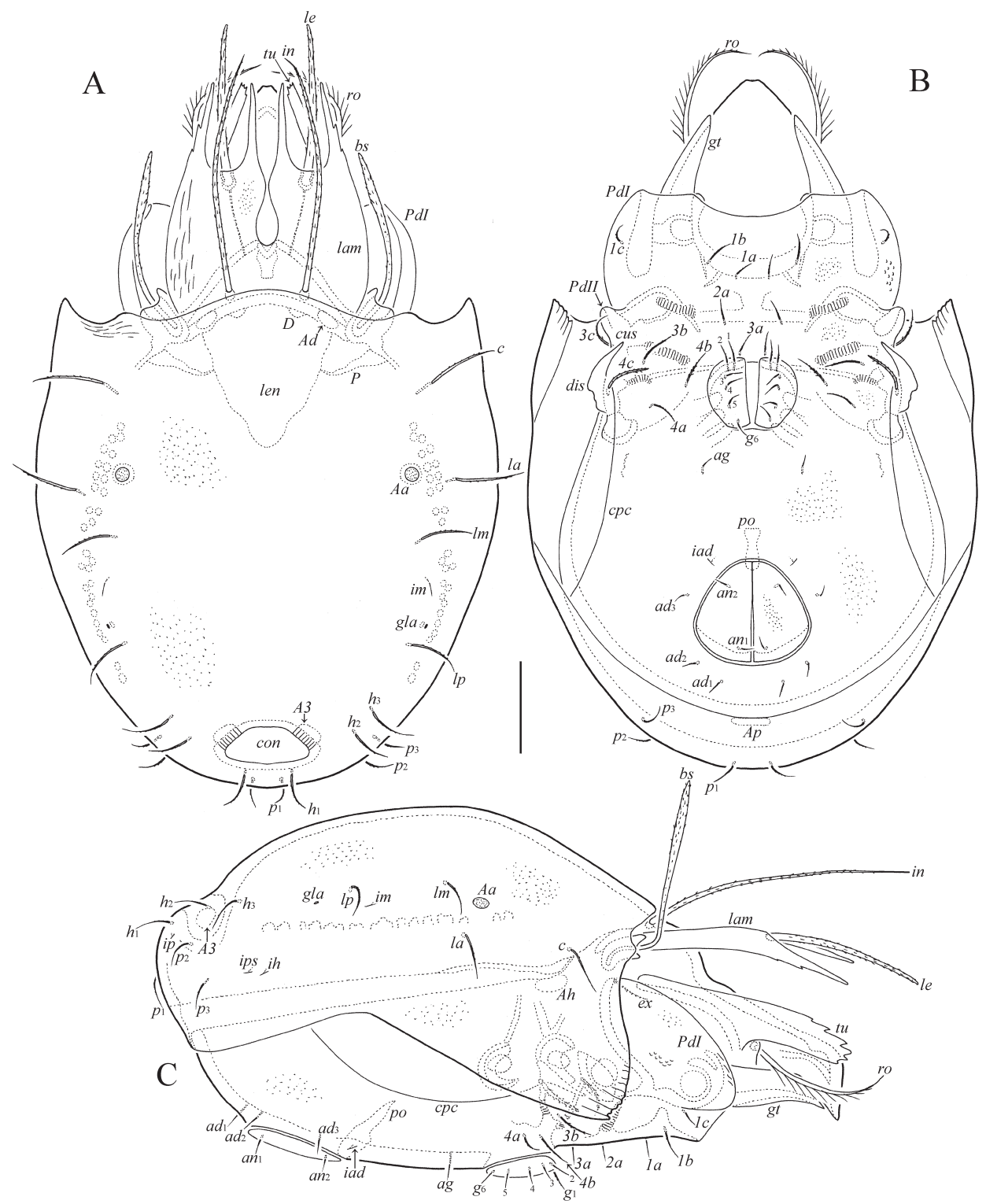

Fig. 1. Oribatella altaica Ermilov sp. n., adult: $\mathrm{A}=$ dorsal view of male (legs not shown); $\mathrm{B}=$ ventral view of male (gnathosoma and legs not shown); $\mathrm{C}=$ right lateral view of male (gnathosoma and legs not shown). Scale bar: $50 \mu \mathrm{m}$ 
prodorsum, setiform, barbed. Bothridial seta long, slightly fusiform, with narrowed head, barbed. Posterior part of notogaster with unpaired concavity in males (versus concavity absent in females). Pteromorph pointed laterally, with several serrations and stria on anterolateral margin. All notogastral setae of medium length, setiform, barbed; $c$ and la longest, $p_{1}-p_{3}$ shortest. Males with two pairs of porose areas ( $A 3$ medially positioned at lateral edges of unpaired concavity in posterior midline); females with three or four pairs of porose areas ( $A 3$ located openly on notogastral surface) or with asymmetrical number of pairs. Epimeral seta $4 c$ longest on epimeres, thickened, barbed; $3 c$
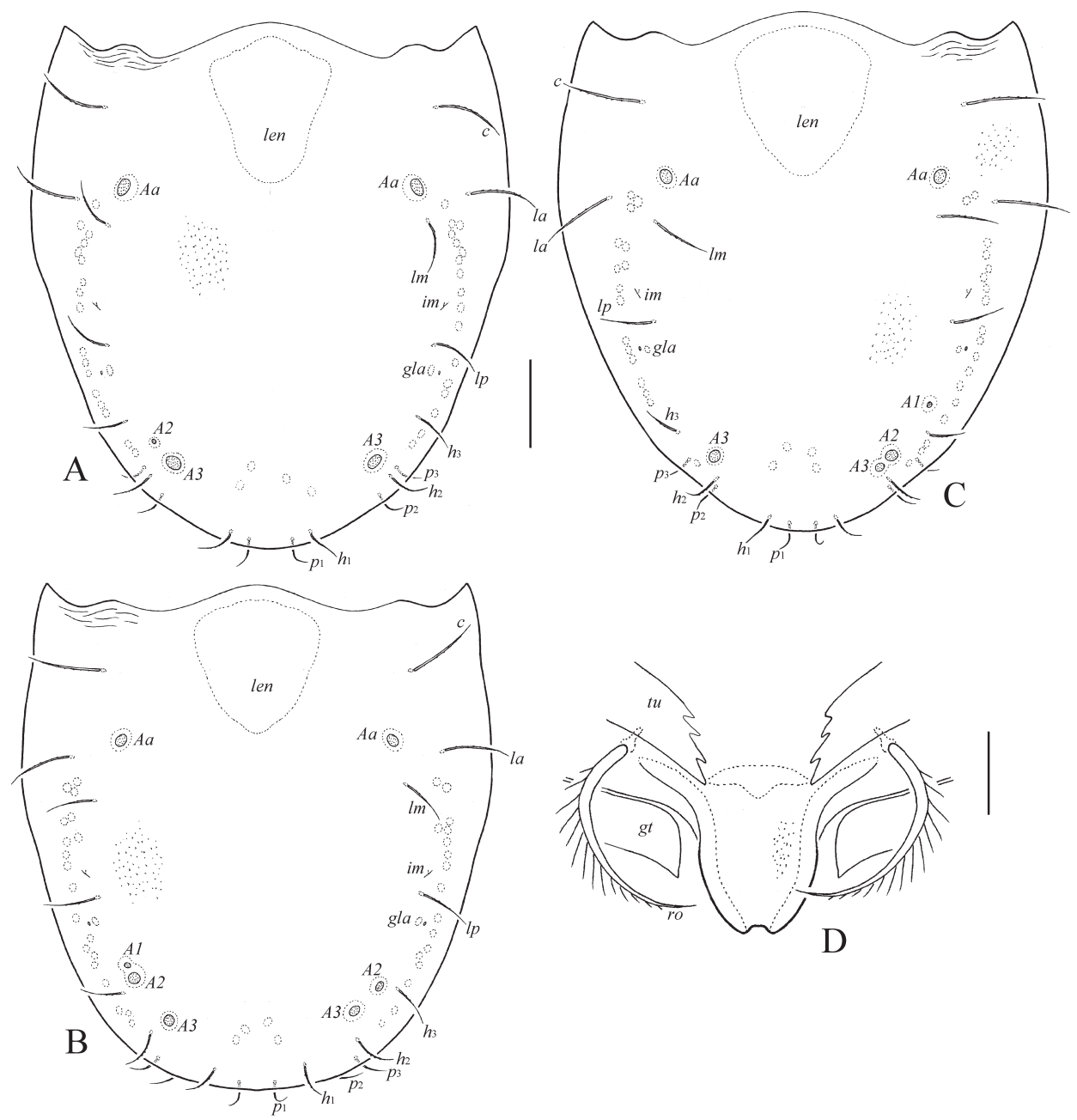

Fig. 2. Oribatella altaica Ermilov sp. n., adult: $A, B, C=$ notogaster of female; $D=$ anterior part of prodorsum, dorsoanterior view. Scale bars: $50 \mu \mathrm{m}(\mathrm{A}, \mathrm{B}, \mathrm{C}), 20 \mu \mathrm{m}(\mathrm{D})$ 
slightly thickened, barbed; others setiform, slightly barbed. Anogenital setae short, setiform, slightly barbed. Postanal porose area elongate oval. Legs heterotridactylous.

Description of adults. Measurements - Body length: 365 (holotype: male), 348-365 (11 male paratypes), 381-398 (12 female paratypes); notogaster width: 215 (holotype), 207215 (11 male paratypes), 232-240 (12 female paratypes).

Integument - Body colour brown. Surface densely microgranulate. Lateral side of lamella, anterior and anterolateral parts of pteromorph and dorsal side of pedotectum I with some stria. Pedotectum I, posterior part of tutorium and ventrolateral part of epimere I tuberculate. Subcapitular mentum sparsely microfoveolate.

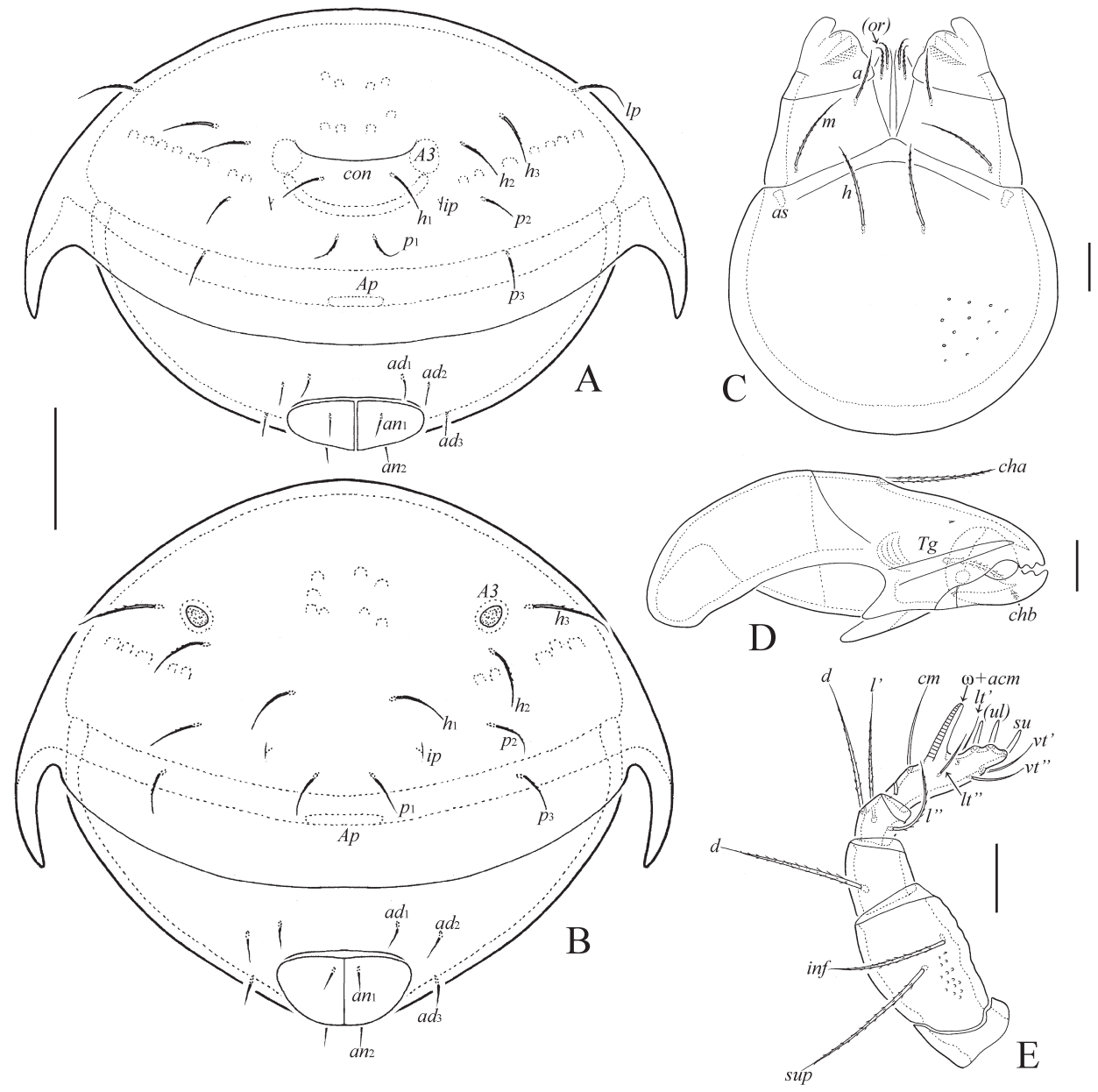

Fig. 3. Oribatella altaica Ermilov sp. n., adult: $\mathrm{A}=$ posterior view of male; $\mathrm{B}=$ posterior view of female; $C=$ subcapitulum, ventral view; $D=$ chelicera, left, paraxial view; $E=$ palp, right, antiaxial view. Scale bars: $50 \mu \mathrm{m}(\mathrm{A}, \mathrm{B}), 10 \mu \mathrm{m}(\mathrm{C}, \mathrm{D}, \mathrm{E})$ 
Table 1. Leg setation and solenidia of adult Oribatella altaica Ermilov sp. n.

\begin{tabular}{lccccc}
\hline Leg & Tr & Fe & Ge & Ti & Ta \\
\hline I & $v^{\prime}$ & $d,(l), b v^{\prime \prime}, v^{\prime \prime}$ & $(l), v^{\prime}, \sigma$ & $(l),(v), \varphi_{1^{\prime}} \varphi_{2}$ & $(f t),(t c),(i t),(p),(u),(a), s,(p v), v^{\prime}$, \\
II & $v^{\prime}$ & $d,(l), b v^{\prime \prime}, v^{\prime \prime}$ & $(l), v^{\prime}, \sigma$ & $(l),(v), \varphi$ & $(f t),(t c),(i t),(p),(u),(a), s,(p v), \omega_{1^{\prime}} \omega_{2}$ \\
III & $l^{\prime}, v^{\prime}$ & $d, l^{\prime \prime}, e v^{\prime}$ & $l^{\prime}, \sigma$ & $l^{\prime},(v), \varphi$ & $(f t),(t c),(i t),(p),(u),(a), s,(p v)$ \\
IV & $v^{\prime}$ & $d, e v^{\prime}$ & $d, l^{\prime}$ & $l^{\prime},(v), \varphi$ & $f t t^{\prime \prime},(t c),(p),(u),(a), s,(p v)$ \\
\hline
\end{tabular}

Note: Roman letters refer to setae, Greek letters to solenidia (except $\varepsilon=$ famulus); single quotation mark (') designates setae on the anterior and double quotation mark (") setae on the posterior side of a given leg segment; parentheses refer to a pair of setae.

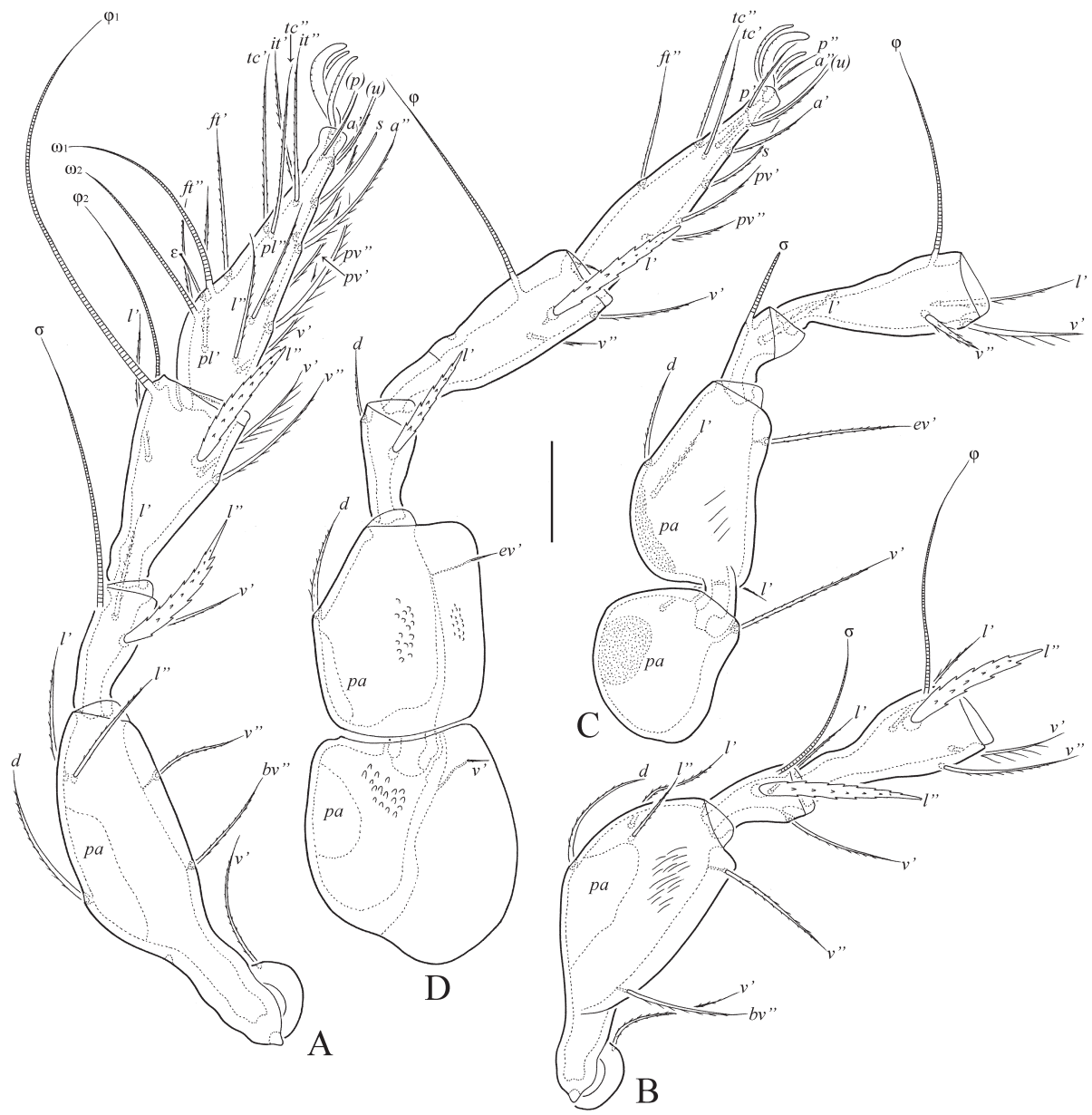

Fig. 4. Oribatella altaica Ermilov sp. n., adult: $\mathrm{A}=$ leg I, right, antiaxial view; B = leg II, without tarsus, right, antiaxial view; $\mathrm{C}=$ leg III, without tarsus, left, antiaxial view; $\mathrm{D}=$ leg IV, left, antiaxial view. Scale bar: $20 \mu \mathrm{m}$ 
Prodorsum - Rostrum protruding, narrowed, with small median concave. Anterior part of prodorsum slightly hump-like. Distal part of lamella with well-developed teeth (outer and inner teeth similar in length, straight, outer tooth laterally with one or two small teeth) and deep U-shaped indentation between them. Inner margins of lamellae separated by elongate oval gap, fused basally by short translamella (median tubercle absent). Rostral seta (77-82) setiform, heavily ciliated unilaterally. Lamellar seta (77-82) bacilliform, barbed. Interlamellar seta (131-135) setiform, nearly straight, barbed. Bothridial seta (8694) fusiform, with slightly developed narrowly elongate head having narrowed distal part,
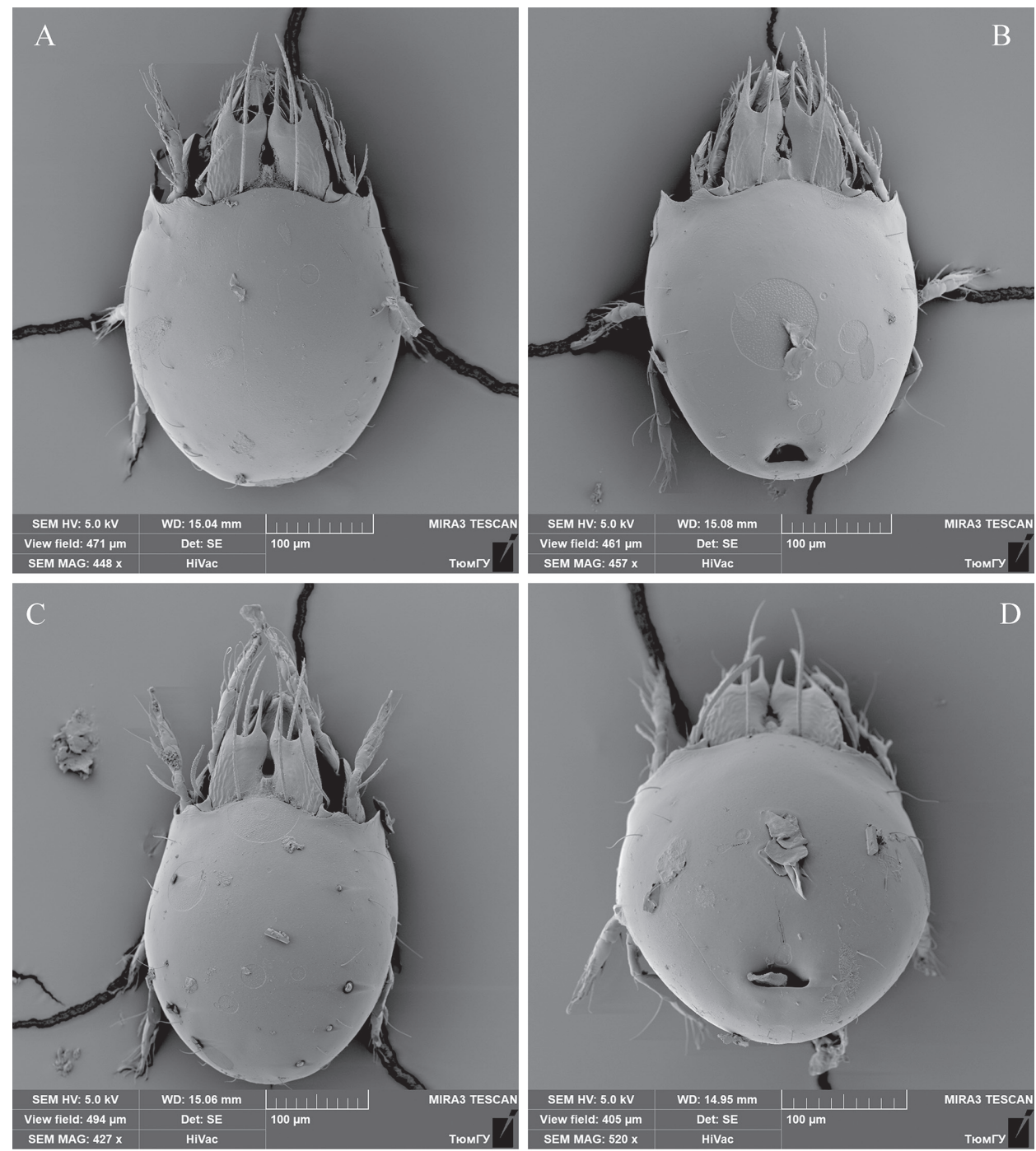

Fig. 5. Oribatella altaica Ermilov sp. n., adult, SEM micrographs: A, C = dorsal view of female; $\mathrm{B}=$ dorsal view of male; $\mathrm{D}=$ dorsoposterior view of male 
barbed. Exobothridial seta (20-24) setiform, slightly barbed. Tutorial cusp with four to six teeth distally. Genal tooth large, rectangular. Dorsosejugal porose area oval, poorly visible.

Notogaster - Anterior margin slightly convex medially. Subtriangular lenticulus well visible. Posterior part of notogaster with large and deep unpaired concavity in males (versus concavity absent in females). Pteromorph pointed laterally, with some serrations on anterolateral margin. Notogastral setae (c: 41-49; la: 41-45; lm, lp, $h_{3}: 28-32 ; h_{1}, h_{2}: 20-24 ; p_{1}-p_{3}$ : 16-20) setiform, barbed. Porose areas rounded (8-12, sometimes some areas reduced up to
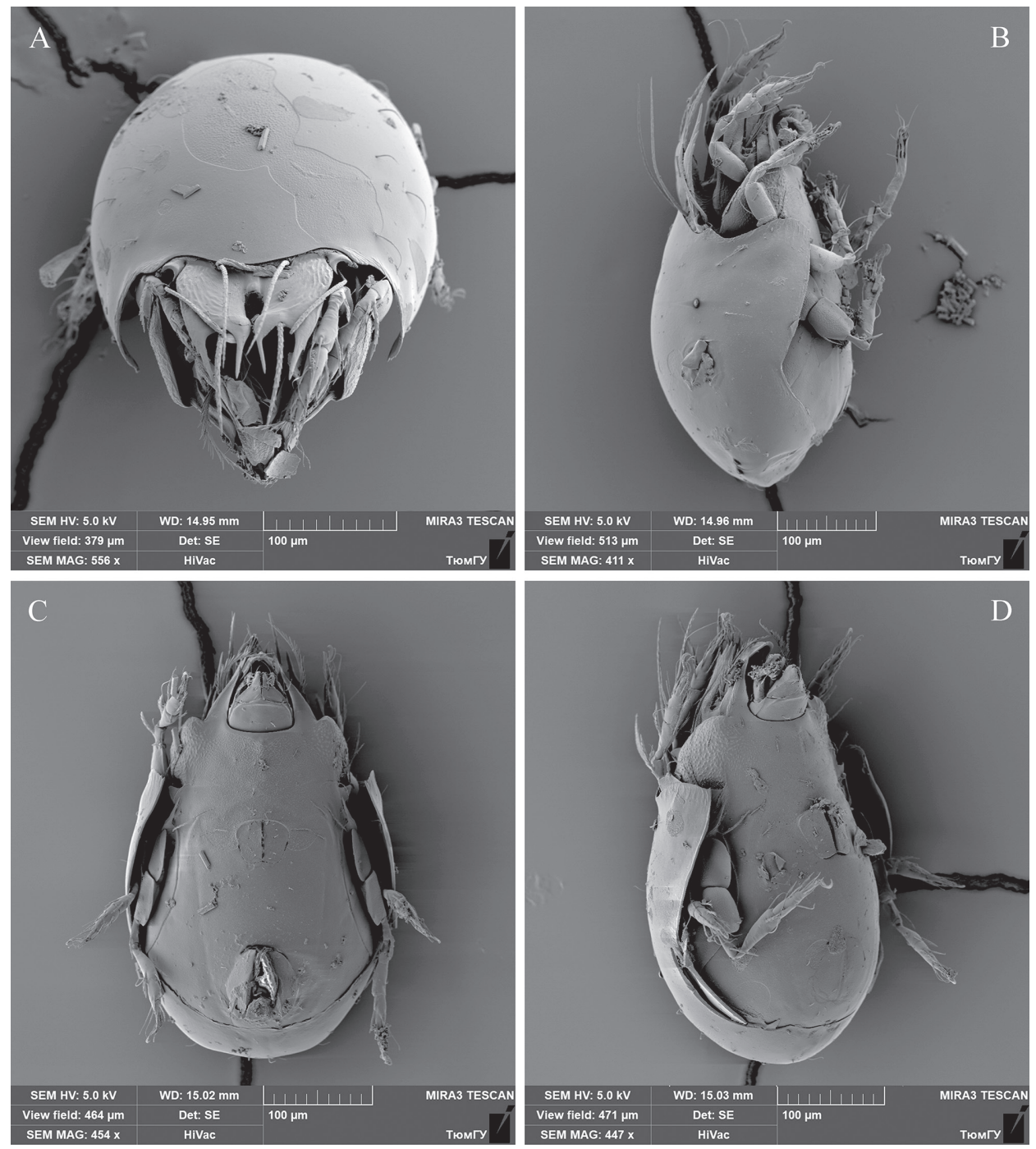

Fig. 6. Oribatella altaica Ermilov sp. n., adult, female, SEM micrographs: $\mathrm{A}=$ dorsoanterior view; $\mathrm{B}=$ lateral view; $\mathrm{C}=$ ventral view; $\mathrm{D}=$ right ventrolateral view 
4); males with two pairs of porose areas, posterior pair (A3) medially positioned at lateral edges of unpaired concavity in posterior midline; some females with three or four pairs of porose areas, but majority of specimens with asymmetrical number of pairs (two versus three, two versus four, three versus four), posterior pair (A3) located openly on notogastral surface. Opisthonotal gland opening and all lyrifissures (except ia not observed) distinct.

Gnathosoma - Subcapitulum size: 82-86 × 65-69. Subcapitular (a: 10-12; m: 20-28; $h$, 20-24) and adoral (6-8) setae setiform, barbed. Palp (length: 61-65) with typical setation $0-2-1-3-9(+\omega)$. Postpalpal seta (4) spiniform, smooth. Axillary saccule distinct, slightly elongated. Chelicera length: 86-94. Cheliceral setae (cha: 24-28; chb: 16) setiform, barbed.

Epimeral and lateral podosomal regions - Epimeral setal formula: 3-1-3-3. Seta $4 c$ (32-41) thickened, barbed; $3 c$ (28-32) slightly thickened, barbed; $3 b, 4 b$ (20-24), 1b, $4 a$ (1620), 1a, 2a, 3a, 1c (12) setiform, slightly barbed. Custodium, discidium and circumpedal carina well developed. Humeral porose area $A h$ oval; $A m$ not observed.

Anogenital region - Genital $\left(g_{1}: 12-14 ; g_{2}: 10-12 ; g_{3}-g_{6}: 8\right)$, aggenital (8), anal (8), and adanal (8) setae setiform, slightly barbed. Adanal setae $a d_{1}$ and $a d_{2}$ located posteriorly, $a d_{3}$ laterally to anal aperture. Adanal lyrifissure inverse diagonal, located close and anterolaterally to anal plate. Postanal porose area elongate oval (20-28 × 6-8).

Legs - Tridactylous; median claw distinctly thicker than laterals, all slightly barbed on dorsal side. Porose area on femora I-IV and on trochanters III, IV well visible. Formulas of leg setation and solenidia: I (1-5-3-4-20) [1-2-2], II (1-5-3-4-15) [1-1-2], III (2-3-1-315) [1-1-0], IV (1-2-2-3-12) [0-1-0]; homology of setae and solenidia indicated in Table 1. Famulus of tarsus I mini-stickform, slightly swollen and blunt-ended apically, inserted posteriorly to solenidion $\omega_{1}$. Seta $s$ of tarsus I eupathidial, located before setae $a$. Setae $l$ " on genua I, II, tibiae I, II and $l^{\prime}$ on genu IV, tibia IV thick, heavily barbed. Solenidia $\omega_{1}, \omega_{2}$ on tarsus II and $\sigma$ on genu III bacilliform, other solenidia setiform.

Material examined - Holotype (male) and 11 paratypes (five males and six females): Russia, Altai, Ongudaysky region, $50^{\circ} 49^{\prime} 52.0^{\prime \prime} \mathrm{N}, 8^{\circ} 37^{\prime} 12.0^{\prime \prime} \mathrm{E}, 1475 \mathrm{~m}$ a.s.l., soil-litter in steppe, 18.07.2021 (collected by A. A. Khaustov, O. Joharchi, I. Döker, and V. A. Khaustov); 12 paratypes (six males and six females): Russia, Altai, Ust-Kansky region, $50^{\circ} 56^{\prime} 11.0^{\prime \prime} \mathrm{N}$, $84^{\circ} 51^{\prime} 35.0^{\prime \prime}$ E, $1525 \mathrm{~m}$ a.s.l., soil-litter in steppe, 18.07.2021 (collected by A. A. Khaustov, I. Döker, V. A. Khaustov, and R. V. Latyntsev).

Type deposition - The holotype and two paratypes are deposited in the collection of the SMNH; twenty-one paratypes are deposited in the collection of the TSUMZ. All specimens are preserved in $70 \%$ solution of ethanol with a drop of glycerol.

Etymology - The specific name altaica refers to the geographical place of origin, Altai.

Remarks - Oribatella altaica Ermilov sp. n. is morphologically most similar to Oribatella canadensis Behan-Pelletier et Eamer, 2010 from Canada in having sexual dimorphism (males with unpaired posterior notogastral concavity versus females without concavity). However, the new species differs from the latter by the presence of microgranulate body surface (versus microfoveolate), slight median indentation of the rostrum (versus indentation deep, with some teeth), slightly fusiform bothridial seta with narrowed head (versus clavate, with rounded head), similar outer and inner teeth on lamella (versus outer tooth 
longer than inner tooth), two pairs of notogastral porose areas in males (versus three pairs), elongate oval postanal porose area (versus oval), epimeral seta $4 c$ distinctly thicker than $3 b, 3 c$ (versus $3 b, 3 c, 4 c$ similar in thickness), and by the absence of a tubercle in the notogastral concavity in males (versus present).

\section{DISCUSSION}

Behan-Pelletier and Eamer (2010) and Behan-Pelletier (2015) summarized data on all known species of brachypyline oribatid mites; altogether 77 species have strong sexual dimorphism. Later, BAYARTоGтокн et al. (2017) described an additional sexually dimorphic species - Neoribates isabelaensis Bayartogtokh, Ermilov et Corpuz-Raros, 2017 (Parakalummidae) - and discussed all cases of sexual dimorphism in the superfamily Oripodoidea.

Cases of sexual dimorphism in the superfamily Oribatelloidea are known only for two representatives of the genus Oribatella, O. canadensis Behan-Pelletier et Eamer, 2010 and O. oregonensis Behan-Pelletier et Walter, 2012. BEHANPelletier and Eamer (2010) described the first sexually dimorphic species of Oribatella - O. canadensis - showing the presence of unpaired concavity with a raised medial region in posterior part of the notogaster in males (versus concavity completely absent in females) and processes different number of notogastral porose areas and localization of $A 3$ (in males: three pairs of areas - $A a, A 1, A 3$ - developed; $A 3$ medially positioned at lateral edges of unpaired concavity in posterior midline versus in females: four pairs of areas - $A a, A 1$, $A 2, A 3$-developed; $A 3$ located openly on notogastral surface). Later, BeHANPelletier and Walter (2015) described the second sexually dimorphic species of Oribatella - O. oregonensis - showing different number of notogastral porose areas and localization of notogastral setae $l p, h_{2}$ and $h_{3}$ (in males: two pairs of areas - $A a$, fused (?) $A 1-A 3$-developed; $l p, h_{2}$ and $h_{3}$ inserted very close to each other on fused (?) $A 1-A 3$ versus in female: four pairs of areas $A a, A 1, A 2, A 3$-developed; $l p, h_{2}$ and $h_{3}$ distant form each other).

The third dimorphic species described herein, Oribatella altaica is similar to O. canadensis in the presence of unpaired posterior notogastral concavity with one pair of porose areas medially positioned at lateral edges of this concavity in posterior midline in males. This modification is not unique for the Oribatella species. A similar sexual dimorphism is also known e.g. in a few representatives of Oppioidea and Oripodoidea (Behan-Pelletier 2015, BAyARTоGтокн et al. 2017). As discussed and summarized earlier (BAYARTOGтокн et al. 2017), certain types of sexual dimorphism, such as modifications in the posterior part of notogaster and octotaxic system, seem to suggest the occurrence of associative mating and even courtship rituals in different oribatid mite groups. Most likely, this is also true for Oribatella altaica, however, 
further studies involving behavioural observation and direct examination of nuptial food are required to determine the role of modifications in the posterior notogastral concavity and porose areas $A 3$, in this species.

Acknowledgements - We are grateful to two anonymous reviewers for valuable comments; A. A. Gubin for SEM micrographs; and R. V. Latyntsev for sampling assistance. This research was supported by cooperative agreement No. FEWZ-2021-0004 from the Russian Ministry of Science and Higher Education.

\section{REFERENCES}

Balogh, J. \& BAlogh, P. (2002): Identification keys to the oribatid mites of the Extra-Holarctic regions. Vol. 1. - Well-Press Publishing Limited, Miskolc, 453 p.

Banks, N. (1895): On the Oribatoidea of the United States. - Transactions of the American Entomological Society 22: 1-16. https://www.jstor.org/stable/25076633

Bayartogtokн, B., Ermilov, S. G. \& Corpuz-Raros, L. (2017): An interesting sexually dimorphic species, Neoribates isabelaensis sp. nov. (Acari, Oribatida, Parakalummidae) with remarks on sexual dimorphism in Oripodoidea. - Zootaxa 4347(1): 94-108. https://doi.org/10.11646/zootaxa.4347.1.5

Behan-Pelletier, V. M. (2011): Oribatella (Acari, Oribatida, Oribatellidae) of eastern North America. - Zootaxa 2973(1): 1-56. https://doi.org/10.11646/zootaxa.2973.1.1

Behan-Pelletier, V. M. (2015): Review of sexual dimorphism in the brachypyline oribatid mites. - Acarologia 55(2): 127-146. https://doi.org/10.1051/acarologia.20152163

Behan-Pelletier, V. M. \& Eamer, B. (2010): The first sexually dimorphic species of Oribatella (Acari, Oribatida, Oribatellidae) and a review of sexual dimorphism in the Brachypylina. - Zootaxa 2332(1): 1-20. https://doi.org/10.11646/zootaxa.2332.1.1

Behan-Pelletier, V. M. \& WAlter, D. E. (2012): Oribatella (Acari, Oribatida, Oribatellidae) of Western North America. - Zootaxa 3432(1): 1-62. https://doi.org/10.11646/zootaxa.3432.1.1

Norton, R. A. (1977): A review of F. Grandjean's system of leg chaetotaxy in the Oribatei (Acari) and its application to the family Damaeidae. Pp. 33-61. In: Dindal, D. L. (ed.): Biology of oribatid mites. - SUNY College of Environmental Science and Forestry, Syracuse.

Norton, R. A. \& Behan-Pelletier, V. M. (2009): Suborder Oribatida. Chapter 15. Pp. 430564. In: Krantz, G. W. \& Walter, D. E. (eds): A manual of acarology. - Texas Tech University Press, Lubbock.

Shtanchaeva, U. Ya. \& Subias, L. S. (2009): A review of oribatid mites of the family Oribatellidae (Acariformes, Oribatida) from the Caucasus. - Zoologichesky Zhurnal 88(2): 143-163. https://doi.org/10.1134/S0013873809020146

Subías, L. S. (2004): Listado sistemático, sinonímico y biogeográfico de los ácaros oribátidos (Acariformes, Oribatida) del mundo (1758-2002). - Graellsia 60 (número extraordinario): 3-305. https://doi.org/10.3989/graellsia.2004.v60.iExtra.218

Subías, L. S. (2021): Listado sistemático, sinonímico y biogeográfico de los Ácaros Oribátidos (Acariformes: Oribatida) del mundo (excepto fósiles), 16ª actualización. 532 pp. Available from http://bba.bioucm.es/cont/docs/RO_1.pdf [accessed March 2021] 
Travé, J. \& Vachon, M. (1975): François Grandjean. 1882-1975 (Notice biographique et bibliographique). - Acarologia 17(1): 1-19.

Weigmann, G. (2006): Hornmilben (Oribatida). Die Tierwelt Deutschlands. Teil 76. - Goecke \& Evers, Keltern, 520 p.

Received August 13, 2021, accepted October 25, 2021, published February 14, 2022 